\title{
Urban Greenways: A Systematic Review and Typology
}

\author{
Olivia S. Horte ${ }^{1}$ and Theodore S. Eisenman ${ }^{2, * \mathbb{B}}$ \\ 1 Rose Kennedy Greenway Conservancy, Boston, MA 02111, USA; ohorte@rosekennedygreenway.org \\ 2 Department of Landscape Architecture and Regional Planning, University of Massachusetts-Amherst, \\ Amherst, MA 01003, USA \\ * Correspondence: teisenman@umass.edu
}

Received: 31 October 2019; Accepted: 12 December 2019; Published: 1 February 2020

\begin{abstract}
Greenways are multifunctional linear landscapes that provide a range of socio-ecological benefits. As a domain of landscape planning research, greenways gained traction in the late 20th century and today, there is substantial interest in greenway planning and design. This is especially true in urban areas, as noted at the sixth Fábos Conference on Landscape and Greenway Planning. Yet, cities encompass biophysical flows, sociopolitical relationships, and formal structures that are distinct from non-urban areas and urban greenways may reflect an evolving type of landscape planning and design that is related to but distinct from greenways writ large. To the best of our knowledge, there has been no previous review of scholarship on greenways in an urban context. We address the aforementioned gaps by reporting on a systematic assessment of peer-reviewed literature. The review encompasses 52 refereed articles using the term "urban greenway" or "urban greenways" in the title, abstract, or keywords drawn from three prominent academic databases. Our analysis covers seven research categories, and this undergirds a typology and definition of urban greenways. In so doing, we seek to illuminate typical traits of urban greenways to inform future landscape planning scholarship and practice.
\end{abstract}

Keywords: urban greenways; urban parks; urban greening; green infrastructure; systematic review; landscape typology

\section{Introduction}

In scholarly literature, greenways have been defined as "networks of land containing linear elements that are planned, designed and managed for multiple purposes including ecological, recreational, cultural, aesthetic, or other purposes compatible with the concept of sustainable land use" [1]. Early use of the "greenway" term can be traced to Elenor Smith Morris' publication of "New urban design concepts: greenways and movement structure: the Philadelphia plan" in Architect's Yearbook [2], and William H. Whyte's The Last Landscape [3], which describes greenways as critical linkages and connectors in a hierarchy of urban green spaces. The idea gained further scholarly traction with Greenways for America [4] and Greenways: A Guide to Planning, Design, and Development [5], followed by two Special Issues of a peer-reviewed journal, Landscape and Urban Planning, dedicated to this topic [6-8].

In practice, however, greenway precedents include tree planting along roads and canals, dating back 2000 years in China [9]; landscape corridors dating to ancient Rome; planted boulevards in 18th century European cities; and the 19th century parkways and park systems of U.S. cities [10,11]. And today, there is substantial interest in greenway planning and design. This is especially true in urban areas due to the growing concentration of people in cities [12], and the limited amount of available space in increasingly built up settlements. Greenways may also be of contemporary interest 
in so-called "legacy" or "shrinking" cities that are characterized by a diminishing population and increasing swaths of vacant land $[13,14]$. As such, urban greenways may be a form of 21st century landscape planning and design that has the potential to address the challenges and opportunities of both expanding and contracting cities, as noted at the 6th Fábos Conference on Landscape and Greenway Planning at which a preliminary version of this study was presented [15].

In this paper, we treat urban greenways as a related but distinct subset of greenways writ large. We believe this is justified for reasons pertaining to pre-existing condition, location, and extent. Regarding pre-existing condition, greenways are often characterized as undeveloped and environmentally sensitive corridors to be conserved in advance of urbanization [1,5]. This highlights the importance of greenways as a sustainable planning strategy to contain or shape urban expansion, reduce land fragmentation, and maintain "landscape integrity" [16], drawing upon scholarship in landscape ecology [17] and subsequent literature on green infrastructure [18], where greenways are critical links/corridors that connect hubs/patches of natural lands to support biotic and abiotic ecological processes. Stated another way: greenways are critical elements of "nature's...pre-existent...super infrastructure" [19].

Pre-existing condition also relates to location. The Oxford English Dictionary, for example, defines a greenway as "a grassy path or way; a piece of undeveloped land near an urban area, set aside for recreational use or environmental conservation" [20]. Regarding extent, greenways are often conceived as a regional, state, national, international or even continental network that can include but generally transcends urban areas [1,11,21-23]. One of the most prominent greenways in the United States, for example, is the Appalachian Trail, which extends some 2190 miles along the eastern mountain chain from which it takes its name; and the experience it is intended to provide is essentially an escape from the urban condition [24].

This is not to suggest that urban areas are not conducive to greenways. Indeed, noteworthy sites in landscape planning history include urban greenways [11]; greenways can constitute a "living network" that provides "people with access to open spaces close to where they live...and link together rural and urban spaces" [25]. Yet, urban areas differ from non-urban areas in important ways, including biophysical flows, sociopolitical dynamics, and formal structure [26-30]. Moreover, in much the same way that urban parks can differ from non-urban parks [31,32], greenways located in highly urbanized areas contend with conditions that can be quite different from non-urban areas [33,34]. Thus, it behooves landscape planners and designers-and associated scholarship — to understand the unique traits of urban greenways to meet the needs of current and future cities.

Towards that goal, this paper addresses the following question: What are the traits that distinguish urban greenway scholarship and practice as an evolving form of landscape planning and design? With this in mind, we address three objectives: (1) illuminate the ways that urban greenways may be a distinct subset of greenways writ large; (2) systematically review scholarly literature on urban greenways; (3) develop a typology and definition of urban greenways. To the best of our knowledge, there has been no previous literature review on greenways in an urban context. Literature reviews are foundational for advancing state-of-the-art understanding of a topic [35,36], and for doing substantive and thorough research [37]. We address this gap and the aforementioned topics by reporting on a systematic literature review of urban greenways and development of an associated typology. Although urban greenways tend to be designed by landscape architects and urban planners, they are also domains of research for a range of fields, including ecology, geography, sociology, wildlife conservation, economics, human health, and others. A systematic review, typology, and definition may, thus, facilitate scholarship on urban greenways across a range of disciplines.

\section{Methods: A Systematic Review}

There are many kinds of literature review and the type of review should be appropriate for the subject and goal at hand [36]. In this case, we conducted a systematic review as there has, to the best of our knowledge been no review on urban greenways, yet greenways are common in urban areas and 
there is a sizable scholarly literature on this topic. As such, a systematic review is appropriate because it helps to clarify the state of existing research and associated implications for future research [38]. In structuring the methodology of this review, we drew upon systematic review precedents in urban greening and landscape planning [35,39].

We searched for the terms "urban greenway" and "urban greenways" through 2018 within the title, keywords, or abstract of three databases: Web of Science, ScienceDirect, and Avery Index to Architectural Periodicals. We then eliminated overlapping results across these database searches. From this pool, we focused on peer-reviewed journal articles and eliminated sources including presentations, posters, book reviews, edited book volumes, magazine articles, encyclopedias, and conference proceedings. This yielded 52 total sources.

We then systematically reviewed these articles across seven categories (see Table 1 and Addendum 1 for the full data set). Most of these (categories 1-5) are based upon precedents in related reviews. But to discern some of the qualities that distinguish urban greenways as a distinct type of landscape form and planning practice, we added two categories: "extent" and "landscape setting." Extent refers to the area covered by the greenway under study, and we use the following classification: urban center (within a municipal boundary); metropolitan (suburban area surrounding an urban center); rural (beyond an urban or suburban area); multi-scalar (a corridor or network that crosses some combination of urban, metropolitan, or rural areas); and multiple sites (studies that examined more than one greenway in different locations).

Table 1. Coding sheet.

\begin{tabular}{|c|c|c|c|}
\hline$\#$ & Review Category & Description & Coding \\
\hline 1 & Journal & Journal of publication & Text: e.g., Urban Studies \\
\hline 2 & Publication Year & Year of publication & Numerical: e.g., 2006 \\
\hline 3 & Study Location & City where study was conducted & Text: e.g., Sapporo \\
\hline 4 & Research Theme & $\begin{array}{l}\text { Main research topic of the paper based on } \\
\text { article keywords classified into a modified } \\
\text { scheme by James et al. (2009) }\end{array}$ & $\begin{array}{l}\text { Text: experience, management, } \\
\text { physicality, valuation }\end{array}$ \\
\hline 5 & $\begin{array}{l}\text { Disciplinary } \\
\text { Orientation }\end{array}$ & Disciplinary orientation of the study & $\begin{array}{l}\text { Text: humanities, natural science, social } \\
\text { science, interdisciplinary/planning }\end{array}$ \\
\hline 6 & Extent & Area covered by the greenway under study & $\begin{array}{l}\text { Text: urban center, metropolitan, rural, } \\
\text { multi-scalar network, multiple sites }\end{array}$ \\
\hline 7 & Landscape Setting & $\begin{array}{l}\text { Predominant landscape setting in which the } \\
\text { greenway is located }\end{array}$ & $\begin{array}{l}\text { Text: adaptive reuse, waterfront, } \\
\text { active/complete street, new build, } \\
\text { multiple settings }\end{array}$ \\
\hline
\end{tabular}

Landscape setting refers to the type of landscape in which the greenway is situated and includes the following classification codes: adaptive reuse (greenways developed along spaces that served a previous use such as highways and railways); waterfront (greenways that run adjacent to water bodies); complete street (greenways that are part of multimodal transit corridors); new-build (greenways that are conserved or designed as part of new development); and multiple settings (greenways located in two or more of the above). A description of each category and associated classification codes is provided in Table 1.

Categories 1-5 were classified based on deductive (a priori) terms drawn from precedent [35]. However, greenway extent and landscape setting were classified inductively based on terms that emerged in the papers under review. In this case, 20 articles were reviewed and classification terms were established based on this sample. Our original review included both study city and the institutional location of the first author origin; however, there was much overlap between the two and we only report on study location.

In two categories-research theme and disciplinary orientation-we diverted slightly from precedent. Drawing upon Bentsen, Lindholst, and Konijnendijk (2008), we use the term "disciplinary 
orientation" instead of "type of science," as the former is, in our opinion, a clearer description of the intent and associated coding terms (humanities, natural science, social science, and interdisciplinary/planning) for this review category. In this category, we also use the term "interdisciplinary" instead of "multiple;" and we added "planning" to this classification scheme, as many of the papers qualify as planning studies and many planning studies address both social and ecological concerns.

Based upon the same review precedent, we also adopted the classification scheme of James et al. [40] to depict the main research theme of the paper. Their original scheme included five classification codes: "physicality, experience, valuation, management, and governance." However, we combined "management" and "governance" into a single classification code ("management") because these terms encompass many overlapping ideas, and it was difficult to disambiguate the two. Physicality encompasses outcomes related to microclimate, soil, air, and water quality functions and is essentially synonymous with "environmental." Experience encompasses people's interaction or contact with green spaces and includes aesthetic, health, and sociocultural dimensions. Valuation encompasses links between green space and economic outcomes, and includes topics such as property value and business development. James et al. (2009) also include ecosystem services-human health and well-being benefits of ecosystem functions that are quantified and monetized-in this category; so we classified ecosystem services in both physicality and valuation. Management encompasses planning, design, and governance of urban greenways. In keeping with precedent, we also included Other for terms that did not directly classify into a priori categories; however, we removed this classification code from the total count as these terms did not address a research theme. To further minimize risk of misclassification in this category, we systematized the process by using the articles' keywords as the underlying source of data. This had the added benefit of providing quantitative data on the scope of terms associated with each research theme.

For categories requiring little subjective determination (categories 1 to 4 ), one co-author coded all papers. For categories requiring some subjective determination (categories 5 to 7), both co-authors reviewed all papers and arrived at a shared classification based on definitions and classification codes described above and listed in Table 1.

In addition to these review categories, we also reviewed articles for definitions of urban greenways and applied keywords from these definitions to a word cloud generator. This systematic review provides a foundation for developing a definition and a typology of urban greenways as a subset of greenways writ large. We drew upon Little (1990) [4], Ahern (1995) [1], Hellmund and Smith (2006) [16], and Rupprecht and Byrne (2014) [41] as precedents for the typology which includes descriptions, goals, and examples of five types of urban greenway. Descriptions and goals were based upon review of scholarship and practice. To acknowledge that greenways within each type can be naturalistic or highly constructed, two photographs are included exemplifying each greenway type across this continuum (see Table 7).

\section{Results}

The results of this systematic review are presented below in the same order as the review categories in Table 1.

\subsection{Journal}

As noted in Table 2, Landscape and Urban Planning has published the most scholarly articles in the urban greenway literature we reviewed, encompassing 21 out of $52(40.3 \%)$ studies. Urban Forestry $\mathcal{E}$ Urban Greening has published three articles (5.8\%) and six journals-International Journal of Sustainable Development and World Ecology, Journal of Environmental Planning and Management, Journal of Leisure Research, Journal of Physical Activity \& Health, Journal of the American Planning Association, and Urban Studies - have each published two articles (3.8\% each). The 16 remaining journals have respectively published one article on urban greenways. 
Table 2. Number of articles per journal.

\begin{tabular}{|c|c|c|c|}
\hline Journal Title & \#of Articles & Journal Title & \#of Articles \\
\hline $\begin{array}{c}\text { American Journal of Preventive } \\
\text { Medicine }\end{array}$ & 1 & $\begin{array}{l}\text { Journal of Outdoor Recreation and Tourism } \\
\text { - Research and Planning Management }\end{array}$ & 1 \\
\hline Ecological Engineering & 1 & Journal of Physical Activity \& Health & 2 \\
\hline Ecosystem Services & 1 & $\begin{array}{l}\text { Journal of the American Planning } \\
\text { Association }\end{array}$ & 2 \\
\hline Environment and Behavior & 1 & $\begin{array}{l}\text { Journal of Urban Planning and } \\
\text { Development - ASCE }\end{array}$ & 1 \\
\hline European Journal of Public Health & 1 & Landscape and Urban Planning & 21 \\
\hline Frontiers of Architectural Research & 1 & Landscape Architecture & 1 \\
\hline $\begin{array}{l}\text { International Journal of Behavioral } \\
\text { Nutrition and Physical Activity }\end{array}$ & 1 & Landscape Research & 1 \\
\hline $\begin{array}{l}\text { International Journal of Environmental } \\
\text { Research and Public Health }\end{array}$ & 1 & Professional Geographer & 1 \\
\hline $\begin{array}{l}\text { International Journal of Sustainable } \\
\text { Development and World Ecology }\end{array}$ & 2 & Science of The Total Environment & 1 \\
\hline $\begin{array}{l}\text { ISPRS International Journal of } \\
\text { Geo-Information }\end{array}$ & 1 & $\begin{array}{l}\text { Transportation Research Part D: Transport } \\
\text { and Environment }\end{array}$ & 1 \\
\hline $\begin{array}{l}\text { Journal of Environmental Planning and } \\
\text { Management }\end{array}$ & 2 & Urban Forestry \& Urban Greening & 3 \\
\hline Journal of Leisure Research & 2 & Urban Studies & 2 \\
\hline
\end{tabular}

\subsection{Publication Year}

As seen in Figure 1, the first mention of urban greenways in the literature captured in this review was in 1995, coinciding with the first of two Special Issues of Landscape and Urban Planning dedicated to this topic [6]. The large spike in 2006 coincides with the second Special Issue of Landscape and Urban Planning [8], accounting for six of the 52 total articles. Of note, there has been a relative surge of urban greenway scholarship over the past four years, with four articles published in 2015, five in 2016, five in 2017, and four in 2018.

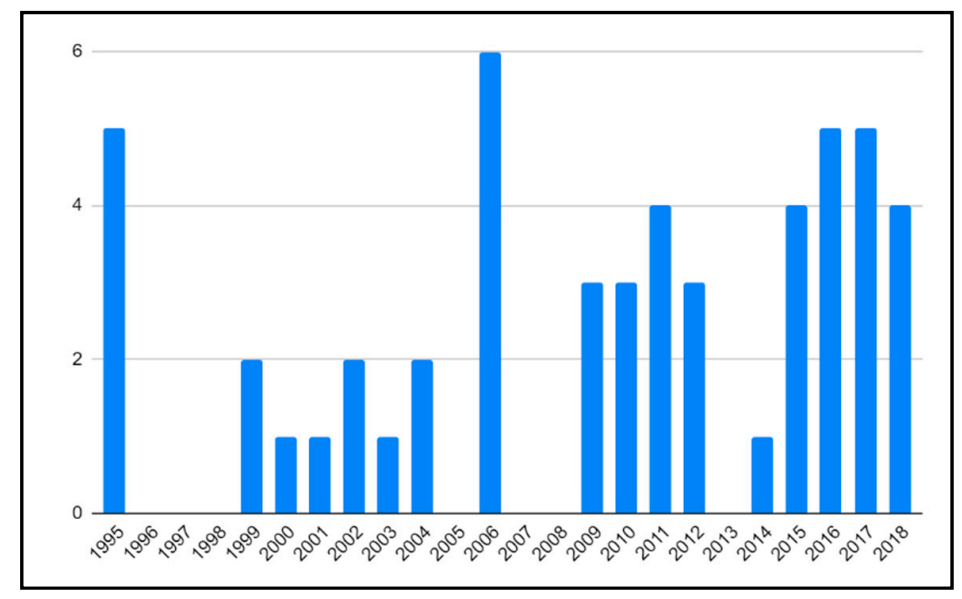

Figure 1. Number of publications by year.

\subsection{Study Location}

As noted in Figure 2, most research on urban greenways has been conducted in the United States-especially the eastern region of the country-and parts of Canada, eastern China, and to a lesser extent, Europe. The cities with greenways that have been studied the most are all in the United States, including Indianapolis, IN (5), Atlanta, GA (4), Knoxville, TN (4), Houston, TX (3), Austin, TX 
(2), and Chicago, IL (2). Greenways in a few non-U.S. cities have also been studied more than once, including Seoul, South Korea (3), Wuhan, China (3), Shenzhen, China (2), Toronto, Canada (2), and Vancouver, Canada (2). Four articles reference multiple cities in their research: one paper focusing on multiple international greenways [8], one review including ten studies from the U.S. and two from Australia [42], one paper referencing multiple cities across the U.S. [10], and one review paper addressing trails and physical activity that included 49 studies from the U.S., two from Australia, and one from New Zealand [43].

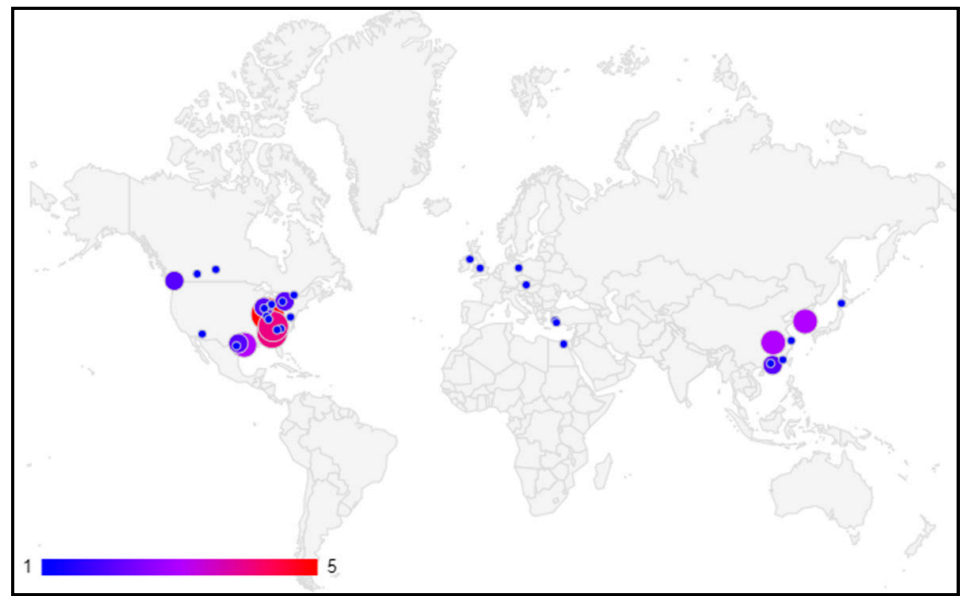

Figure 2. Location of greenway study sites by city.

\subsection{Research Theme}

As noted in Table 3, of the 52 articles included in this review, 297 keywords were used to describe the main themes of the research. Of these keywords, 104 did not directly address a research theme (e.g., names of study locations, methods that could be applied to a range of themes). Thus, we removed these terms from the total count, leaving 193 keywords addressing a research theme. In total, 91 keywords $(47.2 \%)$ focused on human experience, 57 (29.5\%) on management, 37 (19.2\%) on physicality, and eight (4.1\%) on valuation. Two articles did not use keywords: an introduction to a special journal issue [8]; and a longitudinal study on the effects of new urban greenways on transportation energy use and greenhouse gas emissions [44]. For the latter, we added one term to the physicality classification code, making a total of 194 total terms reviewed.

Table 3. Research themes by keyword distribution and examples of topic studied.

\begin{tabular}{cccc}
\hline Research Theme & Examples of Topics Studied & \#of Keywords & Percent \\
\hline Experience of greenways & $\begin{array}{c}\text { human health, recreation, emotions, } \\
\text { perceptions, access, aesthetics, } \\
\text { crime, vandalism, }\end{array}$ & 91 & $46.9 \%$ \\
\hline Management of greenways & $\begin{array}{c}\text { planning, design, governance, } \\
\text { transportation }\end{array}$ & 57 & $29.4 \%$ \\
\hline Physicality of greenways & $\begin{array}{c}\text { habitat corridors, biodiversity, } \\
\text { landscape ecology }\end{array}$ & 38 & $19.6 \%$ \\
\hline Valuation of greenways & $\begin{array}{c}\text { property values, employment } \\
\text { density, hedonic analysis }\end{array}$ & 8 & $100 \%$ \\
\hline Total &
\end{tabular}




\subsection{Disciplinary Orientation}

As illustrated in Table 4, of the 52 articles reviewed, 23 (44.2\%) are based in the social sciences, $23(44.2 \%)$ reflect an interdisciplinary/planning orientation, and six $(11.5 \%)$ are based in the natural sciences. None of the articles are based in the humanities.

Table 4. Distribution of disciplinary orientation.

\begin{tabular}{cccc}
\hline $\begin{array}{c}\text { Disciplinary } \\
\text { Orientation }\end{array}$ & Examples of Topics Studied & \#of Studies & Percent \\
\hline Social Science & $\begin{array}{c}\text { human health, access, aesthetics, } \\
\text { perception, race }\end{array}$ & 23 & $44.2 \%$ \\
\hline Interdisciplinary/Planning & $\begin{array}{c}\text { socio-ecological relations, } \\
\text { alternative futures }\end{array}$ & 23 & $44.2 \%$ \\
\hline Natural Science & $\begin{array}{c}\text { biodiversity, stormwater mgmt., } \\
\text { climate change }\end{array}$ & 0 & $11.5 \%$ \\
\hline Humanities & political ecology, discourse, \\
historiography & $0 \%$
\end{tabular}

\subsection{Extent}

As illustrated in Figure 3, of the 52 studies reviewed, 18 (34.6\%) studied greenways in urban centers, $11(21.2 \%)$ in the metropolitan region surrounding the urban center, and one in a rural area that modeled the stormwater management capability of greenways in the developing urban-rural fringe [45]. Thirteen $(25.0 \%)$ of the studies examined multi-scalar greenways that span some combination of urban, metropolitan, and rural. Nine (17.3\%) articles discuss multiple greenway case studies occurring at different sites, and thus, spanning different extents.

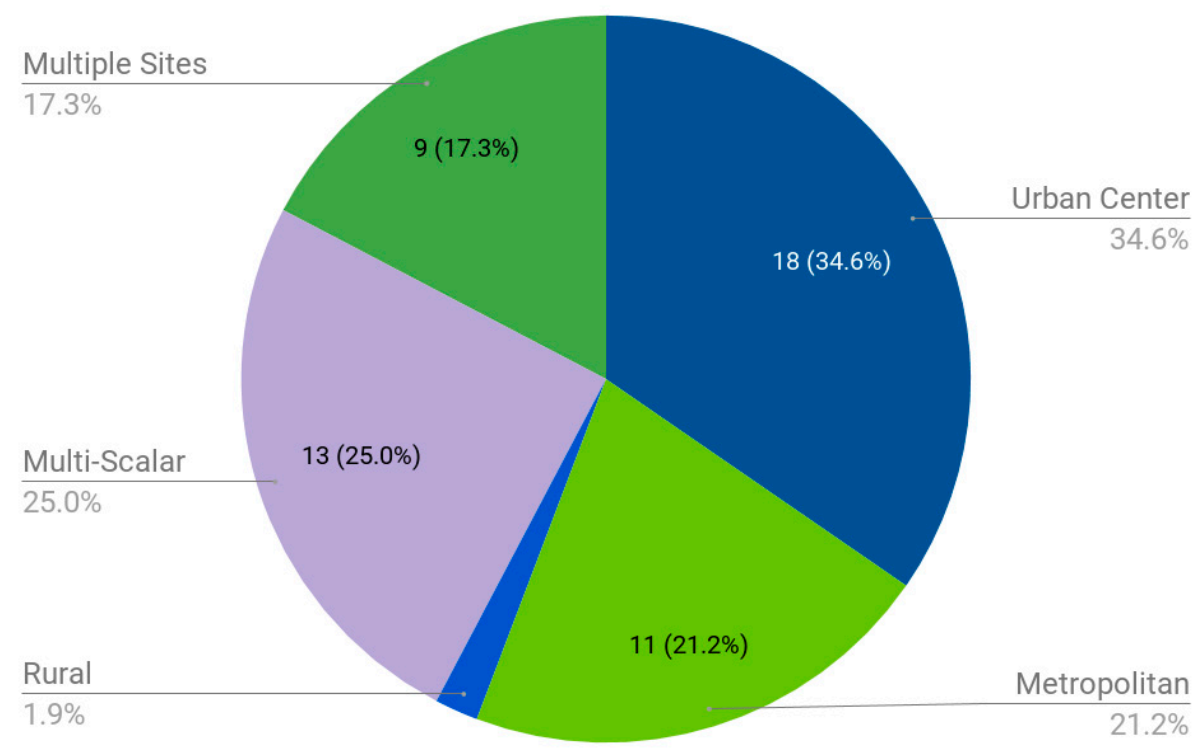

Figure 3. Distribution of urban greenway studies by extent. 


\subsection{Landscape Setting}

As noted in Figure 4, the majority of articles (60.0\%) discuss greenways traversing through more than one landscape setting or multiple greenways in different settings. The next most common setting is adjacent to a water body (22.0\%). Adaptive reuse greenways are the focus of $12.0 \%$ of studies. Finally, $4.0 \%$ of these case studies focus on new on lands that had not previously been developed and one example $(2.0 \%)$ is part of a complete streets network initiative. Of the 52 articles, two did not clarify setting of the greenway(s) in the study and thus, were omitted from the figure and percentages [46,47].

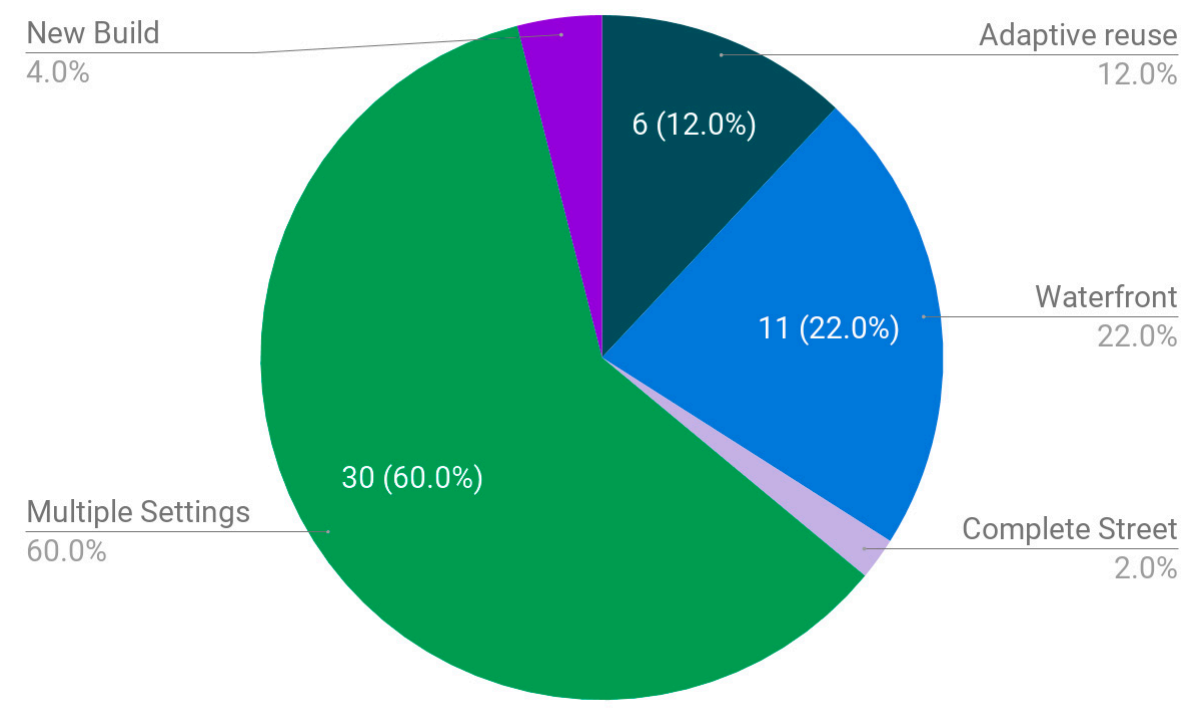

Figure 4. Distribution of urban greenway studies by landscape setting.

\subsection{Definitions}

Of the articles reviewed in our sample, seven provided explicit definitions of urban greenways (see Table 5). To distill the most common themes in these definitions, we removed prepositions, conjunctions, particles, irrelevant verbs (e.g., "defined," "be"), adjectives (e.g., "best," "other"), and adverbs (e.g., "often," "generally"), cited sources, and the terms "urban greenway" and "urban greenways." For consistency, we then edited similar words such as "recreation/recreational," "nature/natural," and "public/public realm" to use the same term. In this vein, we also converted "active travel" to "transportation," as the latter is referring to walking and biking in the context at hand, and active travel (or "active transportation") is synonymous with transportation physical activity in public health literature $[43,48,49]$. The remaining terms were subsequently fed into a word cloud generator, where the frequency of terms is reflected in font size and configuration (see Figure 5). 
Table 5. Definitions of urban greenways.

\begin{tabular}{|c|c|}
\hline Urban Greenway Definitions & Source \\
\hline $\begin{array}{l}\text { "Urban greenways which are often designed with multi-use trails that } \\
\text { provide opportunities for physical activity, recreation and transportation } \\
\text { are defined as places for nature in the city where people can fulfill } \\
\text { recreational needs and achieve solitude and retreat without leaving the } \\
\text { public realm." }\end{array}$ & Akpinar 2016 \\
\hline $\begin{array}{l}\text { "An urban greenway is generally defined as a linear park and } \\
\text { pedestrian-friendly corridor including constructed and natural space." }\end{array}$ & Jang and Kang 2016 \\
\hline $\begin{array}{l}\text { "Almost by definition, urban greenways are places for nature in the city, } \\
\text { places where it is sometimes possible to achieve solitude and retreat, } \\
\text { without leaving the public realm." }\end{array}$ & Luymes and Tamminga 1995 \\
\hline $\begin{array}{l}\text { "Urban greenways are landscaped and traffic-calmed pathways with a } \\
\text { mix of bicycle facilities and other streetscape improvements that link } \\
\text { open spaces, parks, public facilities, and neighborhood centers together. } \\
\text { Greenways support a variety of active travel uses, including walking, } \\
\text { running, bicycling, and skating." }\end{array}$ & Ngo et al. 2018 \\
\hline
\end{tabular}

The Indianapolis Department of Parks and Recreation defines greenways as: "Multi-use trails intended to connect various neighbourhoods of the city and offer increased alternative pedestrian transportation choices."

"For purposes of this paper, we are talking about greenways in urban and urbanizing areas primarily in the USA. Perhaps the best way to find a definition is to look at the two root words, 'green' and 'way'. 'Green' suggests areas that are left vegetated and in most cases appear- or at least strive-to be natural. The word 'way' implies movement, getting Searns 1995 from here to there, from point to point. This is the important distinguishing feature of greenways-they are routes of movement-for people, for animals, for seeds, and, often, for water."

"Urban greenway trails might best be thought of quasi-natural park and open space environments that provide places for daily recreation and alternative transportation options while encouraging positive face to face interaction with other people."

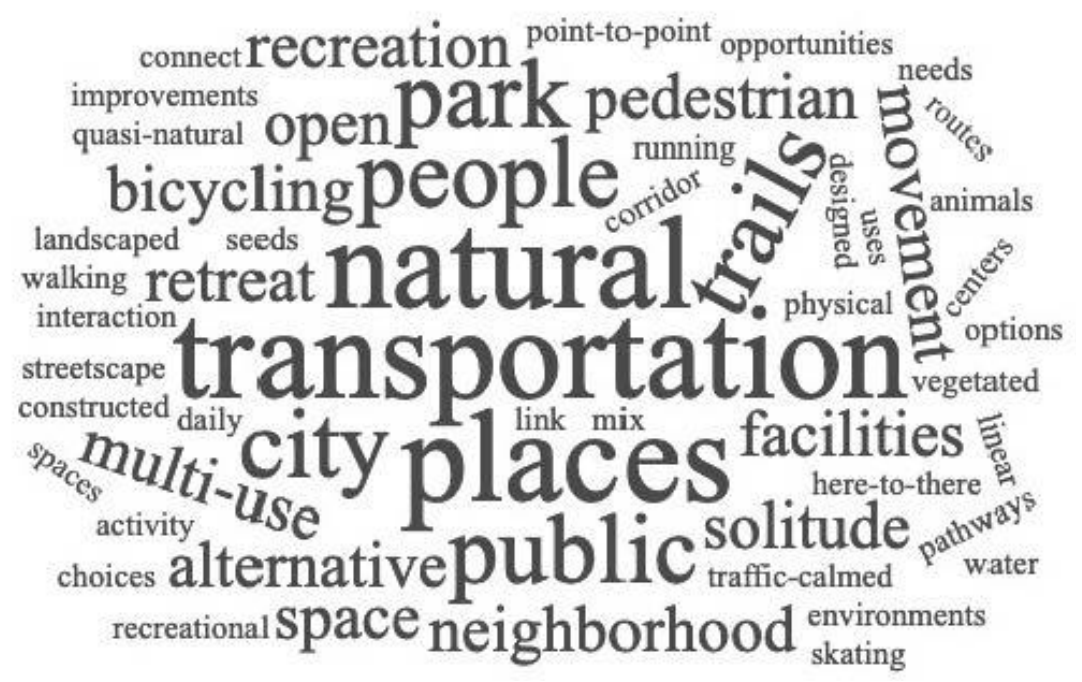

Figure 5. Word cloud of common terms in urban greenway(s) definitions. Developed at https: //www.wordclouds.com/. 


\section{Urban Greenway Typology}

The assessment of literature described above was complemented with the authors' observation of practice to develop a typology of urban greenways. Table 6 includes descriptions, goals, and examples of five types of urban greenway. Table 7 includes photographs exemplifying each greenway type. We offer two photos for each type to illustrate that urban greenways exist along a naturalistic to constructed continuum. For example, rail-to-trails such as the Promenade Plantée (aka Coulée Verte) in Paris include sections both at street level and up to 30-feet high; while the adjacent landscape on many rail-to-trails can be mostly vegetated.

Table 6. Urban greenway typology.

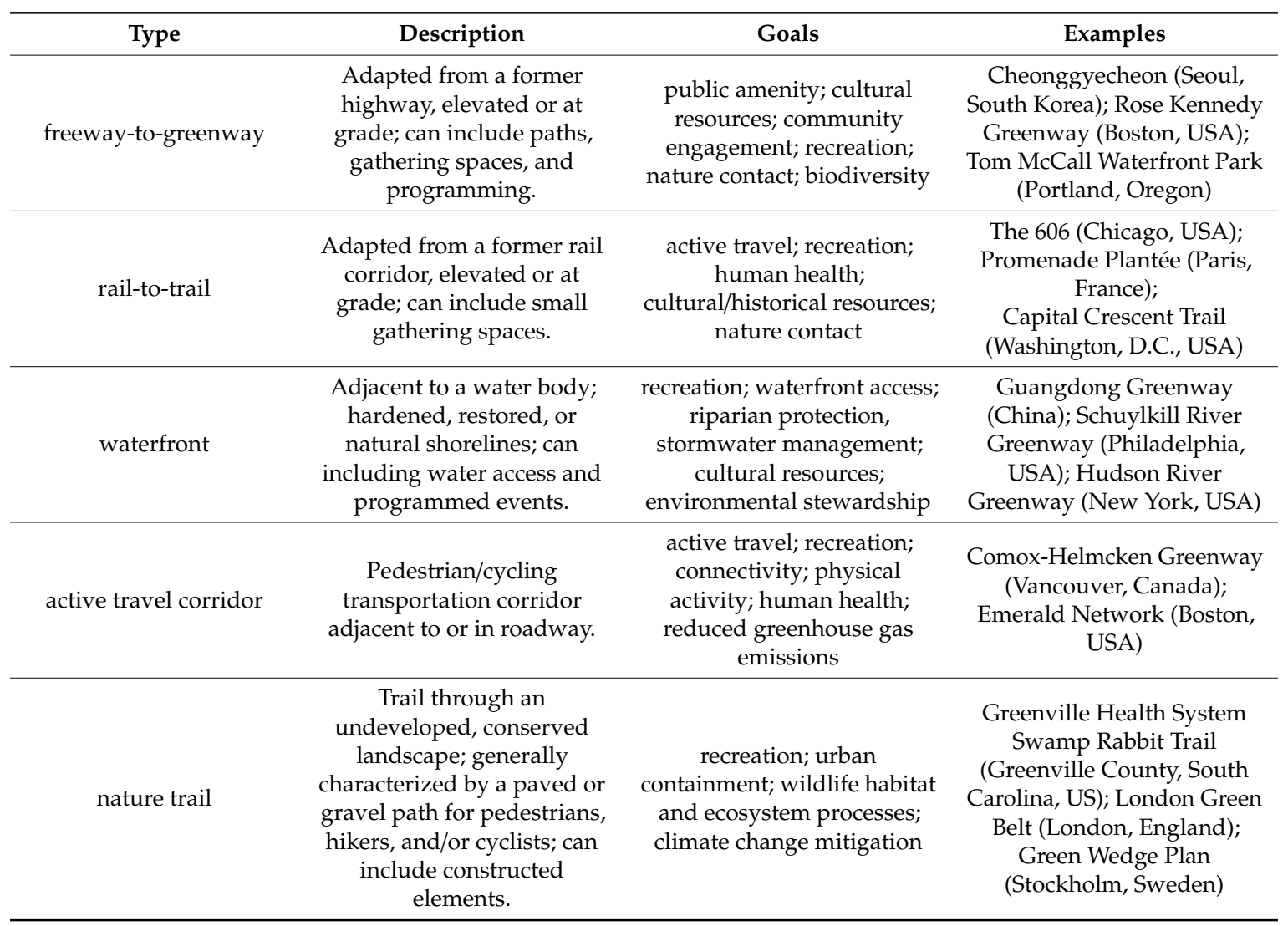

Note: these urban greenways types are often combined into a network. 
Table 7. Urban greenway typology: photographic examples.

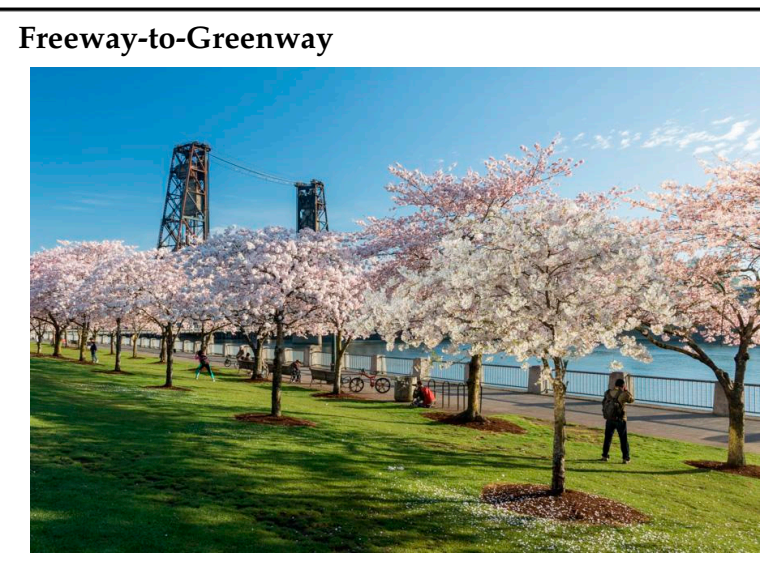

(a). Tom McCall Waterfront Park (Portland, OR, USA) Reproduced with permission from Go4TravelBlog

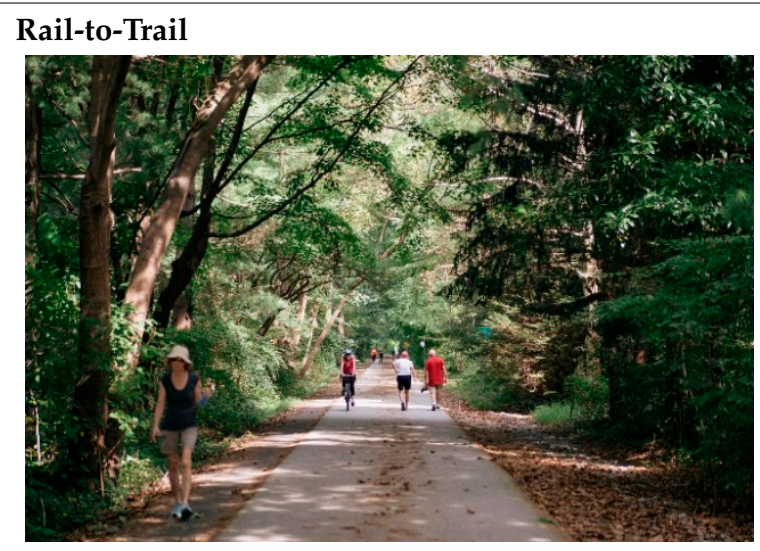

(a). Capital Crescent Trail (Washington, D.C., USA) Reproduced with permission from Rails-to-Trails Conservancy and TrailLink.com

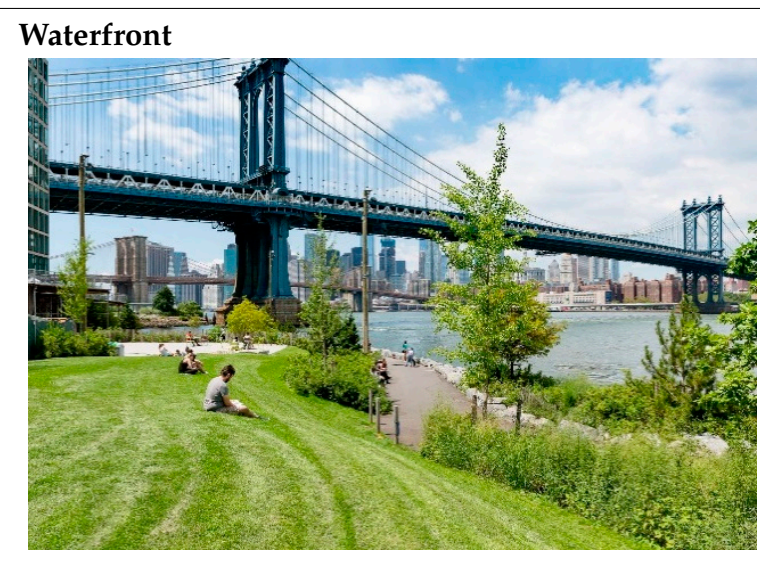

(a). Brooklyn Waterfront Greenway (New York City, USA) Reproduced with permission from Brooklyn Bridge Park Conservancy, photo: (CEtienne Frossard

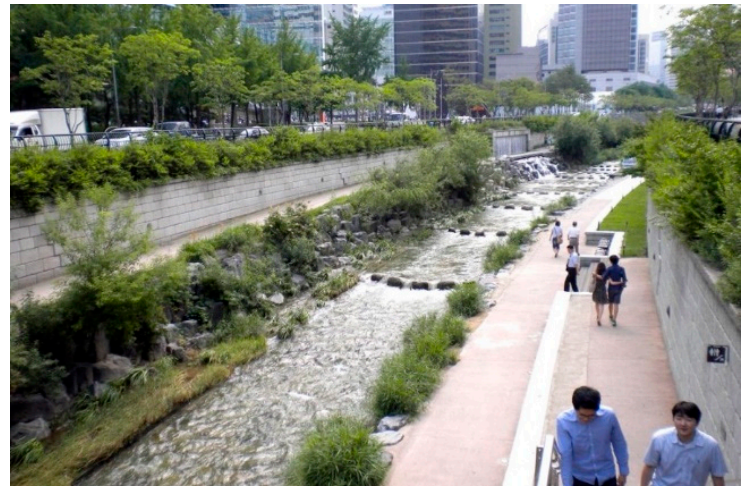

(b). Cheonggyecheon Greenway (Seoul, South Korea) Reproduced with permission from Jaclynn Seah

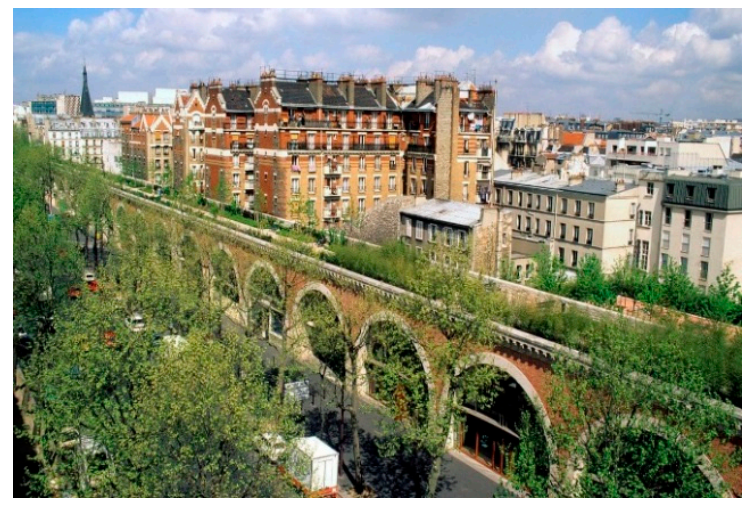

(b). Promenade Plantée (Paris, France) Reproduced with permission from Alamy

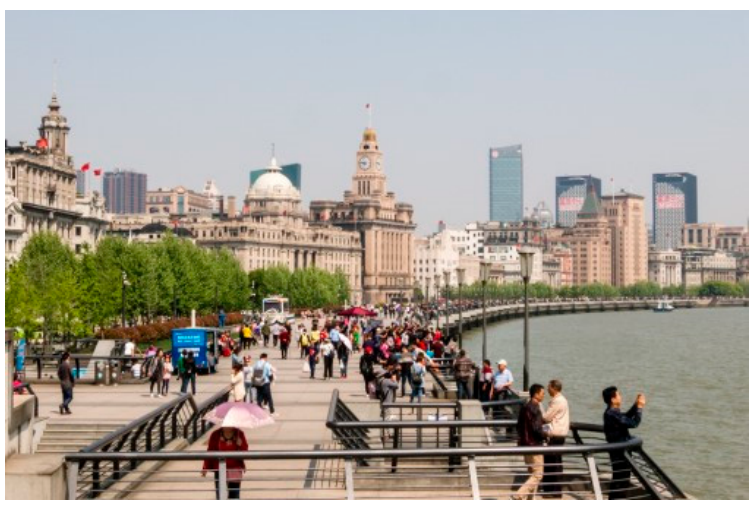

(b). The Bund along the Huangpu River Walk

(Shanghai, China) Reproduced with permission from (C)Richard C. Edwards, 2019 
Table 7. Cont.

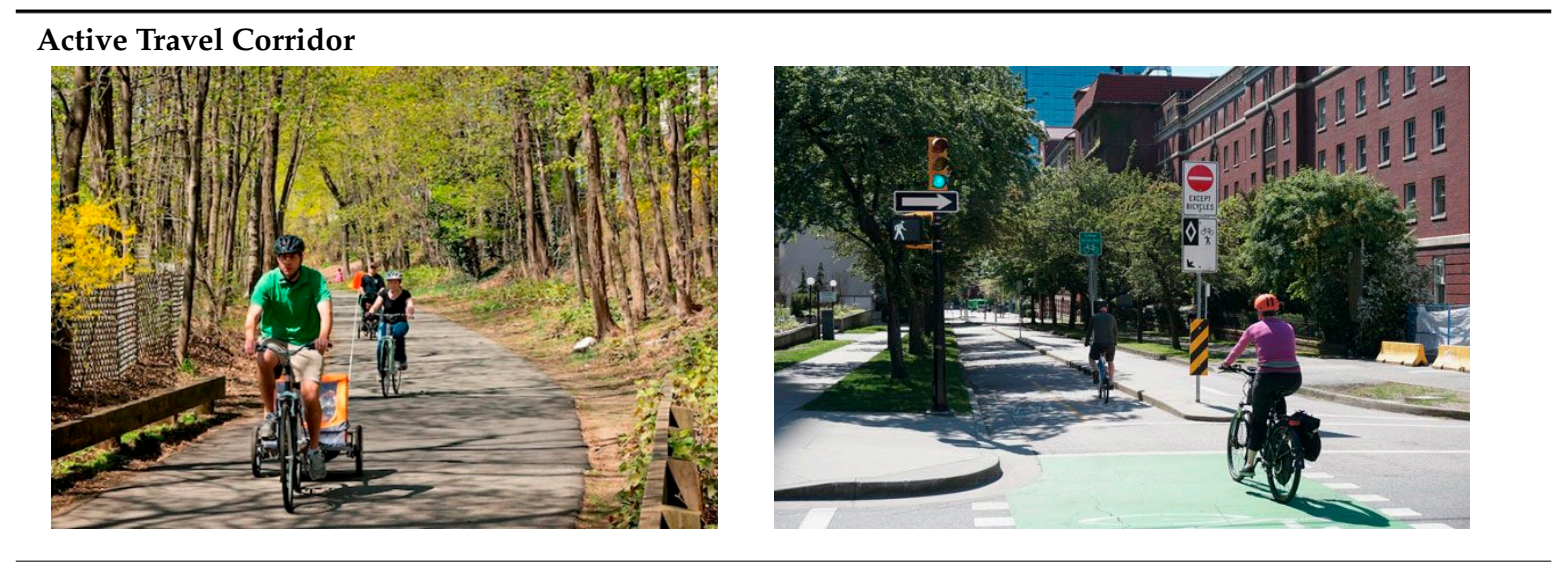

(a). Minuteman Trail, section of the Emerald Network (Boston, USA) Reproduced with permission from Friends of Lexington Bikeways

(b). Comox-Helmcken Greenway (Vancouver, Canada) Reproduced with permission from Ken Ohrn
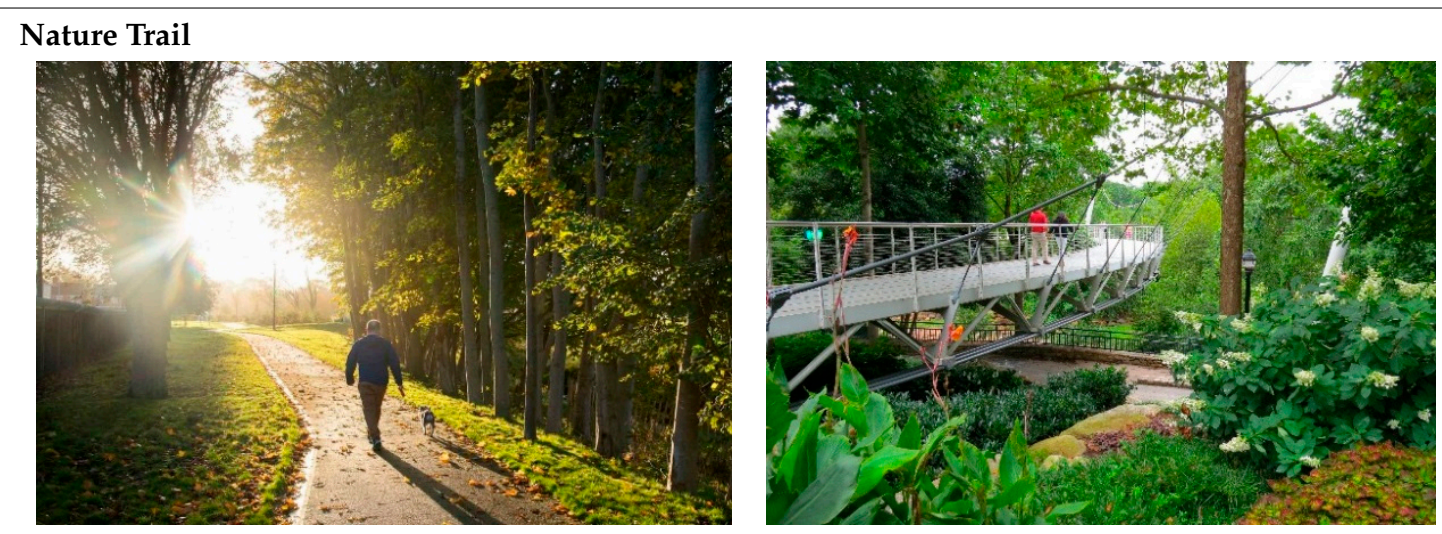

(a). Connswater Community Greenway (Belfast, Ireland) Reproduced with permission from the

(b). Swamp Rabbit Trail (Greenville, SC, USA) Institution of Civil Engineers

Reproduced with permission from All Trails

Note: The selected images are intended to illustrate that urban greenways exist along a naturalistic (left image) to constructed (right image) continuum. Additionally, a greenway can include several types and the various types can be combined into a network.

\section{Discussion}

In the ensuing section we discuss the aforementioned results, interpreting patterns in the data with an eye towards implications for scholarship and practice. In addition to addressing each discrete category, this discussion acknowledges synergies between categories.

\subsection{Journal}

As noted in the results, Landscape $\mathcal{E}$ Urban Planning published over half of urban greenway studies covered in this review. This can be partially explained by the journal having sponsored Special Issues on greenways in 1995 and 2006. Indeed, seven of the 21 studies published by Landscape and Urban Planning that were covered in this review, were published in these Special Issues. Considering the multifunctional nature of greenways, and that greenways are a prominent expression of landscape planning practice, this journal is well-suited to the topic at hand. This is reflected in the journal's aims and scope, guided by an underlying premise that "landscape science linked to planning and design can provide mutually supportive outcomes for people and nature" [50]. The prominence of this journal on urban greenways scholarship is also a testament to the legacy of Julius Gy Fábos, Emeritus Professor of 
Landscape Architecture at the University of Massachusetts, who co-edited the two aforementioned Special Issues.

\subsection{Publication Year}

As noted, the biggest spikes in urban greenway research coincided with two Special Issues of Landscape $\mathcal{E}$ Urban Planning dedicated to this topic $[6,8]$. Special Issues are generally developed when subject experts identify a demand for scholarship in a particular area. High quality Special Issues can, in turn, increase interest in a journal and attract new authors and readers. It should be noted that the recent rise in urban greenway scholarship suggests a broadening disciplinary reach. Of the 18 articles published 2015 to 2018, 14 (77.8\%) were published in journals other than Landscape and Urban Planning. This temporal assessment also reveals a steady increase in scholarly production. There were eight urban greenway articles published from 1995 to 2000, 12 articles from 2001 to 2006, 13 articles from 2007 to 2012, and 19 articles from 2013 to 2018. It is especially noteworthy that growth in urban greenway scholarship over the past decade has occurred independent of special journal issues dedicated to the topic. This illustrates the degree to which urban greenways have gained traction as an important type of landscape planning scholarship and practice.

\subsection{Study Location}

The geographic distribution of urban greenway scholarship reflects a broader pattern in scholarly production, which tends to be dominated by the U.S. and secondarily, China [51]. Related scholarship in ecological planning and design is also dominated by U.S.-based authors [52]. The lack of many studies in Europe is a bit odd, as greenways have a strong tradition there $[10,23,53,54]$. Allied scholarship in urban greening and urban forestry also has strong representation in Europe [35]. The lack of urban greenway scholarship in the global south also reflects patterns in scholarly production writ large, and this is a topic of concern. As noted by Ernstson and Sörlin [55], urban environmental research gestures toward frameworks and models that are valid everywhere, and this risks discounting local knowledge and meaning-making. One study in China, for example, showed that in contrast to studies conducted in Western countries, less-educated and low-income respondents visited an urban greenway more frequently than others [56]. As most 21st century urban growth is expected to occur in Africa and Asia [12], greenway scholarship and planning practice will be especially important in these underrepresented areas. Here, research might address the role and potential of greenways in already built-up urban centers, as well as the potential of greenways to shape future urban development.

\subsection{Research Theme}

The literature reviewed in this study found a strong emphasis on research addressing human needs and values as well as those addressing the planning, design, and management of urban greenways. Constituting roughly three quarters of all studies reviewed, this is not surprising: urban areas are, by definition, dense agglomerations of people and cities are inherently complex and contested settings that require nuanced planning and management. What is perhaps a bit surprising, is the relatively limited body of scholarship explicitly addressing environmental issues (classified here as physicality). This is especially noteworthy considering the strong ecological foundation that undergirds conceptualization of greenways writ large, as noted in the introduction to this paper $[1,5,17,19]$.

It should be noted, however, that many studies did address environmental concerns but they also included social dimensions, whereby they were classified as interdisciplinary. For example, Larson et al. [57] examined how the public perceives ecosystem services of urban greenways and found that people value cultural benefits, such as social gathering and recreation more than environmental functions. This reinforces the need for thoughtful planning and design and striking a balance between programmed/unprogrammed and naturalistic/hard-scaped spaces.

Other studies embrace a socio-ecological approach that addresses both people and the environment, such as benefits that urban greenways provide for mental health and biodiversity [58], and greenways 
as strategies for urban sustainability [59-61]. For example, one study found that for residents living near a newly installed greenway, greenhouse gas emissions decreased by $20.9 \%$ after the greenway's construction and the change in emissions was attributed to a reduction in vehicle kilometers traveled enabled through provision of high-quality active transportation infrastructure through cycling facilities and other streetscape improvements [44].

It is a bit surprising that there are not more studies addressing the economic dimensions (classified here as valuation) of urban greenways. As noted by some studies in the literature reviewed, urban greenways can increase adjacent property values [62,63] and employment density [33]. This can, in turn, be harnessed to finance greenway management through the creation of business improvement districts, exemplified at the Rose Kennedy Greenway in Boston [64]. On the other hand, new green spaces can lead to gentrification and displacement of local residents $[65,66]$. This tension is ripe terrain for expanded research on urban greenways.

\subsection{Disciplinary Orientation}

The findings of this review category—showing that the vast majority of urban greenway research falls into the domain of social science and interdisciplinary research or planning-dovetail largely with the former review category on research themes. Studies addressing social outcomes, for example, include links between urban greenways and user perceptions [67,68], aesthetic response [69], public access [70,71], physical activity levels [46,72], crime [73], and racial commingling [74].

As noted above, the strong social science orientation of urban greenway scholarship is noteworthy in its differentiation from greenways writ large, which has a strong foundation in environmental science and landscape ecology. Yet, the relatively minor emphasis on natural science should not be interpreted as a lack of attention to environmental concerns. Over $40 \%$ of studies in the literature under review adopted an interdisciplinary and/or planning orientation, and this is, in many cases, synonymous with a socio-ecological approach. In urban settings that are built by and for people [28], this is appropriate. Indeed, cities are, in many ways, a classic socio-ecological system where bio-geo-physical elements and processes interact with people and institutions $[75,76]$. Thus, the results of this review can be seen as heartening evidence that scholarship is responding to the practical realities in which urban greenways are embedded.

The lack of humanities-based scholarship on urban greenways is a noteworthy gap. Humanities scholarship draws upon environmental history and political ecology and often adopts a reflexive position that shines a critical light on the topic at hand. Reflecting upon related research in urban forestry and urban greening, Bentsen et al. [35] suggest that a lack of humanities scholarship can reproduce a meta-narrative that only emphasizes benefits and goods. The same may be true for urban greenways research. For relevant examples of humanities scholarship pertaining to urban greenways that were not captured in this review, see Chung et al. [77] and Safransky et al. [78].

\subsection{Extent}

Reflecting the heterogeneous character of urbanized landscapes, studies in this review category were broadly distributed across urban centers (34.6\%), multi-scalar networks $(25.0 \%)$, and metropolitan areas $(21.2 \%)$. This suggests that urban greenways scholarship is addressing a range of scales across urbanized areas and it is encouraging to see many studies addressing multiscalar networks that cut across urban and metropolitan extents. For example, Angold et al. [79] found that small mammals may depend on urban greenways extending from the urban center in Birmingham, UK to adjacent boroughs for dispersal. Cook [80] found that an ecological network plan provides modest but important improvement in ecological systems in the Phoenix urban area. Other multi-scalar studies found that trail use can differ by trail segment [81] and by surrounding land use [82]. Of particular relevance to the topic at hand, the latter study found that greenways surrounded by dense residential and mixed land uses, advanced street networks, and large parks were especially important for increasing physical 
activity. Reflecting Ahern [1], these examples suggest that networks of greenways cutting across scales and land uses are important for generating a range of socio-ecological benefits.

\subsection{Landscape Setting}

Many urban greenways are embedded in a range of landscape settings, as revealed through our assessment, which found that well over half $(60 \%)$ of reviewed studies crossed multiple settings. Another way of interpreting this finding is that urban greenways are doing exactly what they are conceived to do, namely, provide ribbons of green space in landscapes that might otherwise lack green space at all. This is especially true in the complex, heterogeneous fabric of urban areas, where land contestation can make green space provision all the more difficult.

The next most common setting is waterfronts. This is not surprising, as riparian corridors are routinely identified as one of-if not the-most common settings for greenways [1,4,19]. Studies on waterfront greenways address a range of topics, including but not limited to, stream rehabilitation and public access [83], dispersal corridors for invasive trees [84], and links between human perception, safety, and use [85]. One study found that waterfront greenways close to residential zones, employment centers, and key public services such as hospitals and schools increase use [71]. Focusing on the urban-rural fringe, McGuckin and Brown [46] found that stormwater management facilities can be integrated into existing greenways, and if protected during development, can generate a range of socio-ecological benefits.

Reflecting an ongoing movement to reconceive outdated urban landscapes, a handful of studies address one of the boldest and most dramatic "freeways-to-greenways" to date. In Seoul, Korea, the Cheonggyecheon freeway was torn down and replaced by an urban stream and linear park in 2003-2004, making this project both a good example of adaptive reuse and waterfront greenway. Research shows that land value premiums for parcels within the $500 \mathrm{~m}$ walkshed of urban greenway entrance points were notably higher than former freeway on-ramps [62]. Related studies also found that employment density increased within a $1.2 \mathrm{~km}$ zone surrounding the new urban greenway [33], and that land conversion from single-family residential to commercial was more likely to occur within $1.5 \mathrm{~km}$ of greenway pedestrian entrances.

It is worth noting that freeway-to-greenway projects-including early precedents in Portland, Oregon and San Francisco, California-are harbingers of similar projects being explored in other cities [62]. These are complex feats of civil engineering layered with substantial political and economic mobilization. The transformative effect of such projects may foretell increased scholarship on the complex planning, design, and management of such multi-layered landscapes, as well as interconnected effects related to land use change, property value, public access, and equity.

\subsection{Definitions}

As noted in Table 5 and Figure 5, urban greenway definitions highlight certain recurring themes including "transportation," "natural," "public," people," and "places." If we aggregate terms such as "walking," "pedestrian," "bicycling," "skating," "pathways," "routes," "trails," "movement," "traffic-calmed," and "streetscape," it is clear that non-motorized transportation in the form of walking and biking is a dominant idea running across urban greenway definitions. Likewise, terms such as "landscaped," "vegetated," and "natural" connote flora and greenery. In sum, the definitions offered here are largely synonymous with one of four greenway definitions offered by Little [4], p. 1): "any natural or landscaped course for pedestrian or bicycle passage."

One aspect that is, however, missing from this definition is that urban greenways are also "public places," as noted in our review. The notion of "place" is an important, albeit nuanced, idea. The term is often conflated with "space." But space is an abstract term that has no correlation with human experience. In other words, space has no inherent meaning. A place, on the other hand, signifies a space that has social meaning, and this meaning is mediated by human experience [86]. Thus, urban greenways are not merely vegetated corridors for non-vehicular transportation, they are linear public 
parks that can provide amenities we normally associate with urban parks writ large: places for public gathering; places for nature contact and recreation; and places of civic pride. The Rose Kennedy Greenway, for example, has transformed downtown Boston. Running along the roof of a submerged highway, the greenway includes a series of contemporary parks designed by landscape architects that include public art, food trucks, farmers' markets, fountains, a carousel, and a visitor center for the Harbor Islands, all of which is bound together by vegetated areas. With this in mind, we offer the following definition: "Urban greenways are linear public parks and places that facilitate active travel and recreation in urban areas."

The anthropocentric focus of urban greenway definitions is noteworthy. Indeed, none of the seven definitions that emerged in this review explicitly references non-human environmental processes, organisms, or values. This is quite different from scholarly characterizations and definitions of greenways writ large, where wildlife and ecosystem processes and patterns rooted in landscape ecology figure prominently.

\subsection{Urban Greenways Typology}

The typology of urban greenways described in Section 4 above illuminates some noteworthy traits of urban greenways. In urban centers, greenways are often implemented in highly constructed landscapes that formerly served another purpose. This is exemplified in the Cheonggyecheon freeway-to-greenway, as well as the Rose Kennedy Greenway. Colloquially known as the "Big Dig," this project depressed the Central Artery of Interstate 93-an elevated six-lane highway completed in 1959-and in its place created a 1.5-mile greenway through the heart of the city (see Figure 6). This reflects a late 20th and early 21st century urban parks movement to repurpose and adaptively reuse outdated landscapes such as landfills, elevated rails and highways, and parking lots [32]. It also reflects efforts to redesign the auto-centric landscape that dominated mid-20th century urban planning.

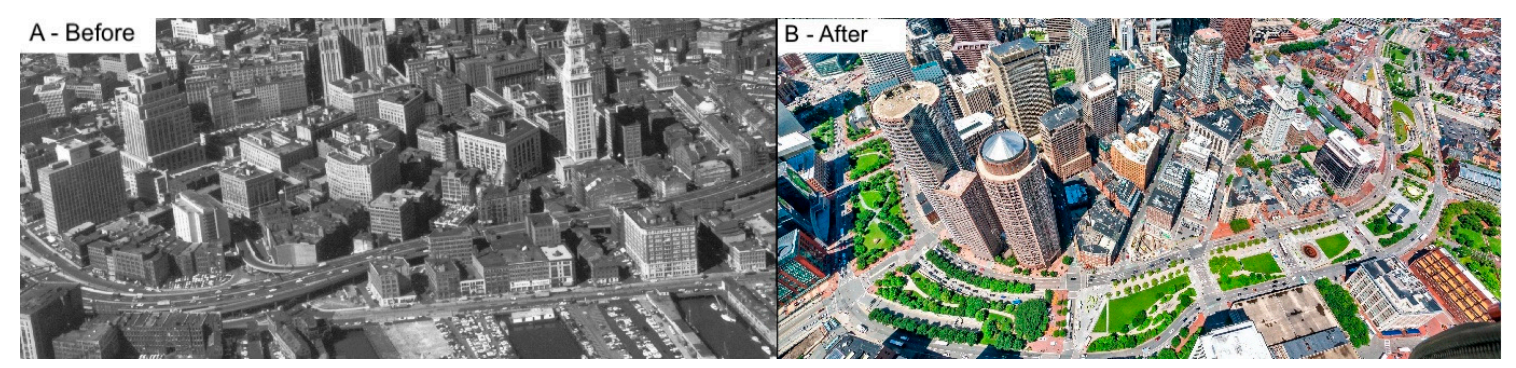

Figure 6. (A) The Central Artery highway running through the city in 1962. (B) Rose Kennedy Greenway in 2017 following depression of the Central Artery. Photo A: Reproduced with permission from the Massachusetts State Archives. Photo B: Reproduced with permission from the Rose Kennedy Greenway Conservancy, photo: (CKyle Klein

Another contemporary expression of this aspiration is the active travel corridor exemplified in Boston's Emerald Network initiative and the Comox-Helmcken Greenway in Vancouver, Canada (see Figure 7). A unifying theme in these greenways is the redesign of existing streets to accommodate cyclists, including infrastructural interventions, such as: (1) new and upgraded traffic signals; (2) new street paving, concrete medians and curb bulges, catch basins, paint, and signage; (3) new sidewalks, curb ramps, and raised crosswalks; (4) new and upgraded street, sidewalk, and park lighting; and (5) new public realm amenities, such as seating, planting, trees, drinking fountains, and wayfinding features [49].

Similar to the freeway-to-greenway and rail-to-trail examples, these contemporary expressions of urban greenways adaptively reuse existing urban landscapes for new purposes. From a planning perspective, these adaptive reuse types of greenways can be considered an "offensive strategy," in that they introduce new elements in previously disturbed or fragmented landscapes [1]. This resonates with depictions of urban greening as a social practice of organized or semi-organized efforts to introduce, 
conserve, or maintain outdoor vegetation in urban areas $[87,88]$. In many cases, adaptive reuse greenways include new plantings and a net increase in flora and biomass. This may not, however, always be the case with active travel corridors, where new plantings are just one of many structural design elements and many stretches may have little if any vegetation.

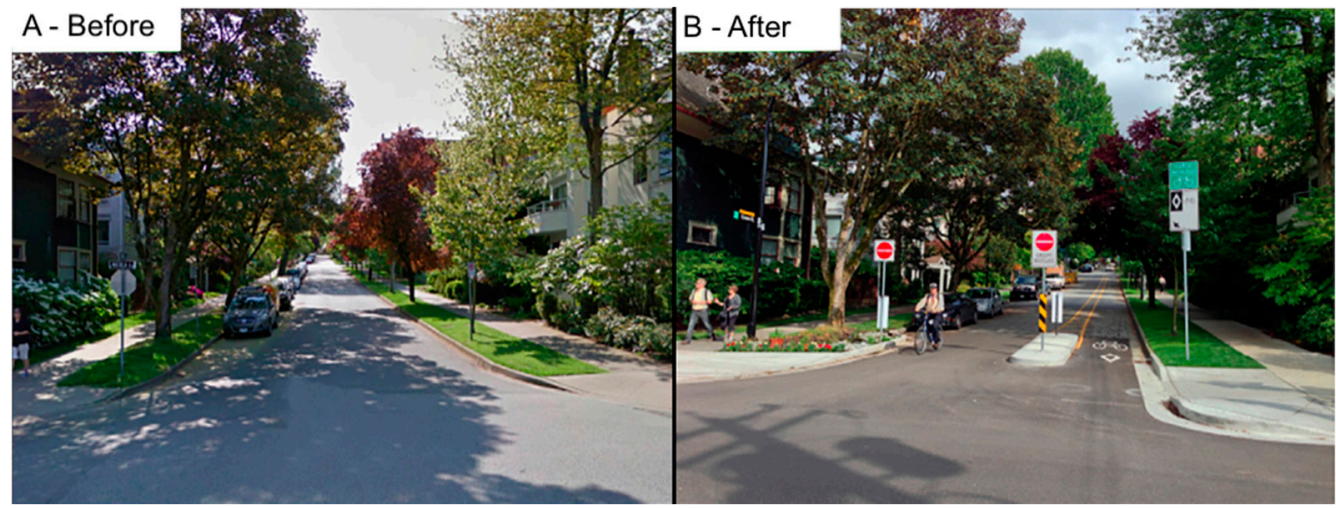

Figure 7. The Comox-Helmcken streetscape before (A) and after (B) greenway construction. Photo A: Google Street View; Photo B: Reproduced with permission from Paul Krueger, City of Vancouver

This represents a departure from the original conception of greenways, where "green" is synonymous with "nature" or "flora" [4,5,19]. In urban areas, by contrast, "green" coupled with "ways" can signify a broader sustainability and livability agenda. This reflects popular and scholarly discourse on "green cities," which addresses topics including transportation, energy, food systems, and social equity, and climate change in particular [89-92]. The lack of much vegetation in contemporary expressions of greenways as active travel corridors might be perceived as corrupting the greenway construct. It is worth noting, however, that related terms have undergone similar changes. For example, early conceptualization of "green infrastructure" had a strong wildlife conservation orientation that drew upon landscape ecology as a strategy to protect and restore regional hubs and corridors of natural lands/habitat from development [18,93]. The term, however, also became synonymous with low-impact development and stormwater management, where the primary goal is to hold or infiltrate stormwater directly in the ground-often but not always through vegetated systems-instead of channeling runoff into traditional grey infrastructure culverts and pipes that discharge into nearby surface waters [94-96]. Some have even extended the green infrastructure construct to include solar panels, wind turbines, public art installations, and outdoor theaters [97].

Another noteworthy theme of urban greenways is that they exist along a naturalistic to highly constructed continuum. This is clearly the case for freeways-to-greenways, rail-to-trails, and active travel corridors, all of which are new constructions layered upon previous constructions. It is also the case for nature trails, which can include compacted gravel and paved paths as well as constructed bridges. This also applies to waterfront greenways in urban centers, which tend to have hardened shorelines and are often built on fill. But as riverfront greenways extend from urban centers to less densely developed landscapes, the waterfront can assume an increasingly naturalistic condition, as exemplified in the Schuylkill River Greenway in Philadelphia, USA. In some cases, urban greenway planning can include regrading and planting of vegetation to actively restore waterfronts to a naturalistic condition, as exemplified in the Chicago River corridor [98].

\subsection{Qualifiers}

We recognize that there are likely peer reviewed articles addressing urban greenways that this review did not capture. For example, some greenway studies may have been conducted in an urban context but they did not use the term "urban greenway" or "urban greenways" in the title, abstract, or keywords; and there may be studies that were not included in the databases we searched. Thus, 
this paper should not be read as a comprehensive assessment of any and all peer reviewed studies on greenways in an urban context. On the other hand, urban ecology has shown that the urban context can have different meanings, especially in an urbanizing world where the ecological footprint of cities can extend to global scales [99-101]. Thus, a constructive attribute of this study is that it focuses explicitly on studies addressing landscapes described as urban greenway(s) in the title, abstract, or keywords, and in so doing, provides a focused snapshot of this literature. An additional caveat is that distilling research into discrete categories and sub-coding these categories into discrete classes, can be a subjective and reductionistic act, both of which have inherent problems. Subjective classification is based on the assessors' interpretation, which can introduce unconscious bias and error [102]. Reductionism can, in turn, oversimplify complex relationships [103,104]. With these caveats in mind, categorization and classification can be helpful when seeking to advance understanding of a complex topic or phenomenon.

\section{Conclusions}

This study reports on a systematic assessment of 52 peer-reviewed articles using the term "urban greenway" or "urban greenways" in the title, abstract, or keywords, and covering seven research categories plus definitions. The review finds that there has been an uptick in urban greenway scholarship over the past decade; that urban greenway scholarship and definitions reflect a strong orientation towards human needs and concerns; that many urban greenways adaptively reuse already developed lands; and that the materiality of urban greenways ranges from naturalistic to highly constructed. In urban areas, "green" coupled with "ways" may signify a sustainability and livability agenda that goes beyond vegetation per se. The paper offers a definition of urban greenways and outlines an urban greenways typology that includes: freeway-to-greenway, rail-to-trail, waterfront, active travel corridor, and nature trail. As a subset of greenways writ large, urban greenways reflect an evolving form of landscape planning and design, and an opportunity for associated scholarship and practice.

Author Contributions: Conceptualization: T.S.E. Methodology T.S.E., O.S.H. Formal analysis: O.S.H., T.S.E. Investigation: O.S.H., T.S.E. Data curation: O.S.H. Writing-original draft preparation: O.S.H., T.S.E. Writing-review and editing: T.S.E., O.S.H. Visualization: O.S.H. Supervision: T.S.E. Project administration: O.S.H., T.S.E. All authors have read and agree to the published version of the manuscript.

Funding: This research received no external funding. However, much of the open access publishing fee was provided by the University of Massachusetts-Amherst.

Acknowledgments: We would like to thank Jack Ahern for providing constructive comments on the first author's University of Massachusetts-Amherst Commonwealth Honors College senior thesis, which undergirds this study. We also extend thanks to Maria Håkansson and Tigran Haas in the Department of Urban Planning and Environment at KTH Royal Institute of Technology in Stockholm, Sweden for supporting the corresponding author as a visiting scholar in fall 2019. Additionally, we thank The Rose Kennedy Greenway Conservancy for providing time for the first author to work on this article.

Conflicts of Interest: The authors declare no conflict of interest.

\section{References}

1. Ahern, J. Greenways as a Planning Strategy. Landsc. Urban Plan. 1995, 33, 131-155. [CrossRef]

2. Morris, E.S. New Urban Design Concepts: Greenways and Movement Structure: The Philadelphia Plan. Archit. Yearb. 1965, 11, 26-40.

3. Whyte, W.H. The Last Landscape; University of Pennsylvania Press: Philadelphia, PA, USA, 1968.

4. Little, C.L. Greenways for America; Johns Hopkins University Press: Baltimore, MD, USA, 1990.

5. Flink, C.; Searns, R. Greenways: A Guide to Planning Design and Development, 1st ed.; Schwarz, L.L., Ed.; Island Press: Washington, DC, USA, 1993.

6. Fabos, J.G.; Ahern, J. Greenways. Landsc. Urban Plan. 1995, 33, 1-482. [CrossRef]

7. Fabos, J.G.; Ryan, R.L. International Greenway Planning. Landsc. Urban Plan. 2004, 68, 143-146. [CrossRef] 
8. Fabos, J.G.; Ryan, R.L. An Introduction to Greenway Planning around the World. Landsc. Urban Plan. 2006, 76, 1-6. [CrossRef]

9. Yu, K.; Li, D.; Li, N. The Evolution of Greenways in China. Landsc. Urban Plan. 2006, 76, 223-239. [CrossRef]

10. Searns, R.M. The Evolution of Greenways as an Adaptive Urban Landscape Form. Landsc. Urban Plan. 1995, 33, 65-80. [CrossRef]

11. Fabos, J.G. Greenway Planning in the United States: Its Origins and Recent Case Studies. Landsc. Urban Plan. 2004, 68, 321-342. [CrossRef]

12. Angel, S. Planet of Cities; Lincoln Institute of Land Policy: Cambridge, MA, USA, 2012.

13. Mallach, A. Rebuilding America's Legacy Cities: New Directions for the Industrial Heartland; Mallach, A., Ed.; The American Assembly, Columbia University: New York, NY, USA, 2012.

14. Schilling, J.; Logan, J. Greening the Rust Belt: A Green Infrastructure Model for Right Sizing America's Shrinking Cities. J. Am. Plan. Assoc. 2008, 74, 451-466. [CrossRef]

15. Fabos, J.G.; Ahern, J.; Breger, B.; Eisenman, T.S.; Jombach, S.; Kollanyi, L.; Lindhult, M.S.; Ryan, R.L.; Valanszki, I. Adapting to Expanding and Contracting Cities. In Proceedings of the Fábos Conference on Landscape and Greenway Planning, Amherst, MA, USA, 28-30 March 2019; Volume 6.

16. Hellmund, P.C.; Smith, D.S. Designing Greenways: Sustainable Landscapes for Nature People; Island Press: Washington, DC, USA, 2006.

17. Forman, R.T.T. Land Mosaics: The Ecology of Landscapes and Regions; Cambridge University Press: Cambridge, UK; New York, NY, USA, 1995.

18. Benedict, M.A.; McMahon, E.T. Green Infrastructure: Smart Conservation for the 21st Century. Renew. Resour. J. 2002, 20, 12-17.

19. Fabos, J.G. Introduction and Overview: The Greenway Movement, Uses and Potentials of Greenways. Landsc. Urban Plan. 1995, 33, 1-13. [CrossRef]

20. Oxford English Dictionary. Greenway, n. OED Online; Oxford University Press: Oxford, UK, 2019.

21. Benedict, M.A.; McMahon, E. Green Infrastructure. [Electronic Resource]: Linking Landscapes and Communities; Island Press: Washington, DC, USA, 2006.

22. Lynch, A.J. Is it Good to be Green? Assessing the Ecological Results of County Green Infrastructure Planning. J. Plan. Educ. Res. 2016, 36, 90-104. [CrossRef]

23. von Haaren, C.; Reich, M. The German Way to Greenways and Habitat Networks. Landsc. Urban Plan. 2006, 76, 7-22. [CrossRef]

24. McKay, B. An Appalachian Trail: A Project in Regional Planning. In Architectural Regionalism: Collected Writings on Place, Identity, Modernity; Canizaro, V.B., Ed.; Princeton Architectural Press: New York, NY, USA, 2006; pp. 225-236.

25. President's Commission of American Outdoors. American Outdoors: The Legacy, the Challenge; Island Press: Washington, DC, USA, 1987.

26. Kostof, S. The City Shaped: Urban Patterns and Meanings Through History; Thames and Hudson: London, UK, 1991.

27. Costanza, R.; D’Arge, R.; De Groot, R.; Farber, S.; Grasso, M.; Hannon, B.; Limburg, K.; Naeem, S.; O’Neill, R.V.; Paruelo, J.; et al. The Value of the World's Ecosystem Services and Natural Capital. Nature 1997, 387, 253-260. [CrossRef]

28. Groffman, P.M.; Cavender-Bares, J.; Bettez, N.D.; Grove, J.M.; Hall, S.J.; Heffernan, J.B.; Hobbie, S.E.; Larson, K.L.; Morse, J.L.; Neill, C.; et al. Ecological Homogenization of Urban USA. Front. Ecol. Environ. 2014, 12, 74-81. [CrossRef]

29. IPBES, (Intergovernmental Science-Policy Platform on Biodiversity and Ecosystem Services). The Regional Assessment Report on Biodiversity and Ecosystem Services for the Americas: Summary for Policymakers; IPBES Secretariat: Bonn, Germany, 2018; p. 41. ISBN 978-3-947851-01-0.

30. Wentz, E.A.; York, A.M.; Alberti, M.; Conrow, L.; Fischer, H.; Inostroza, L.; Jantz, C.; Pickett, S.T.A.; Seto, K.C.; Taubenböck, H. Six Fundamental Aspects for Conceptualizing Multidimensional Urban form: A Spatial Mapping Perspective. Landsc. Urban Plan. 2018, 179, 55-62. [CrossRef]

31. Garvin, A. Public Parks: The Key to Livable Communities; W. W. Norton \& Company: New York, NY, USA; London, UK, 2011.

32. Harnik, P. Urban Green: Innovative Parks for Resurgent Cities; Island Press: Washington, DC, USA, 2010. 
33. Jang, M.; Kang, C.-D. The Effects of Urban Greenways on the Geography of Office Sectors and Employment Density in Seoul, Korea. Urban Stud. 2016, 53, 1022-1041. [CrossRef]

34. Rose Kennedy Greenway Conservancy. Annual Report 2018; Rose Kennedy Greenway Conservancy: Boston, MA, USA, 2019; p. 12.

35. Bentsen, P.; Lindholst, A.C.; Konijnendijk, C.C. Reviewing Eight Years of Urban Forestry \& Urban Greening: Taking Stock, Looking Ahead. Urban For. Urban Green. 2010, 9, 273-280.

36. Galvan, J.L.; Galvan, M.C. Writing Literature Reviews: A Guide for Students of the Social and Behavioral Sciences, 7th ed.; Routledge: Taylor and Francis Group: New York, NY, USA; London, UK, 2017.

37. Boote, D.N.; Beile, P. Scholars Before Researchers: On the Centrality of the Dissertation Literature Review in Research Preparation. Educ. Res. 2005, 34, 3-15. [CrossRef]

38. Feak, C.B.; Swales, J.M. Telling a Research Story: Writing a Literature Review; University of Michigan Press: Ann Arbor, MI, USA, 2009.

39. Luederitz, C.; Brink, E.; Gralla, F.; Hermelingmeier, V.; Meyer, M.; Niven, L.; Panzer, L.; Partelow, S.; Rau, A.-L.; Sasaki, R.; et al. A Review of Urban Ecosystem Services: Six Key Challenges for Future Research. Ecosyst. Serv. 2015, 14, 98-112. [CrossRef]

40. James, P.; Tzoulas, K.; Adams, M.D.; Barber, A.; Box, J.; Breuste, J.; Elmqvist, T.; Frith, M.; Gordon, C.; Greening, K.L.; et al. Towards an Integrated Understanding of Green Space in the European Built Environment. Urban For. Urban Green. 2009, 8, 65-75. [CrossRef]

41. Rupprecht, C.D.D.; Byrne, J.A. Informal Urban Greenspace: A Typology and Trilingual Systematic Review of Its Role for Urban Residents and Trends in the Literature. Urban For. Urban Green. 2014, 13, 597-611. [CrossRef]

42. Benton, J.S.; Anderson, J.; Hunter, R.F.; French, D.P. The Effect of Changing the Built Environment on Physical Activity: A Quantitative Review of the Risk of Bias in Natural Experiments. Int. J. Behav. Nutr. Phys. Act. 2016, 13, 107. [CrossRef] [PubMed]

43. Starnes, H.A.; Troped, P.J.; Klenosky, D.B.; Doehring, A.M. Trails and Physical Activity: A Review. J. Phys. Act. Health 2011, 8, 1160-1174. [CrossRef] [PubMed]

44. Ngo, V.D.; Frank, L.D.; Bigazzi, A.Y. Effects of New Urban Greenways on Transportation Energy Use and Greenhouse Gas Emissions: A Longitudinal Study from Vancouver, Canada. Transp. Res. Part Transp. Environ. 2018, 62, 715-725. [CrossRef]

45. McGuckin, C.P.; Brown, R.D. A Landscape Ecological Model for Wildlife Enhancement of Stormwater Management Practices in Urban Greenways. Landsc. Urban Plan. 1995, 33, 227-246. [CrossRef]

46. Wolff, D.L.; Fitzhugh, E. The Relationships Between Weather-Related Factors and Daily Outdoor Physical Activity Counts on an Urban Greenway. Med. Sci. Sports Exerc. 2010, 42, 247-248. [CrossRef]

47. Quayle, M. Urban Greenways and Public Ways-Realizing Public Ideas in a Fragmented World. Landsc. Urban Plan. 1995, 33, 461-475. [CrossRef]

48. Owen, N.; Humpel, N.; Leslie, E.; Bauman, A.; Sallis, J.F. Understanding Environmental Influences on Walking: Review and Research Agenda. Am. J. Prev. Med. 2004, 27, 67-76. [CrossRef]

49. Sallis, J.F.; Cervero, R.B.; Ascher, W.; Henderson, K.A.; Kraft, M.K.; Kerr, J. An Ecological Approach to Creating Active Living Communities. Annu. Rev. Public Health 2006, 27, 297-322. [CrossRef]

50. Landscape and Urban Planning. Aims \& Scope. Available online: https://www.journals.elsevier.com/ landscape-and-urban-planning (accessed on 29 October 2019).

51. SJR, (Scimago Journal \& Country Rank). International Science Ranking. Available online: https://www. scimagojr.com/countryrank.php (accessed on 30 October 2019).

52. Eisenman, T.S. The Ecological Design and Planning Reader. J. Plan. Educ. Res. 2016, 37, 374-376. [CrossRef]

53. Jongman, R.H.G.; Külvik, M.; Kristiansen, I. European Ecological Networks and Greenways. Landsc. Urban Plan. 2004, 68, 305-319. [CrossRef]

54. De Oliveira, F.L. Green Wedge Urbanism: History, Theory and Contemporary Practice; Bloomsbury Academic: New York, NY, USA, 2017.

55. Lewis, J.; Sawyer, L.; Spirn, A.W.; Ávila, M.; Walker, R.A.; Hoffman, L.M.; Baviskar, A.; Lachmund, J.; Van Sittert, L.; Evans, J.; et al. Grounding Urban Natures: Histories and Futures of Urban Ecologies; Urban and Industrial Environments; Ernstson, H., Sörlin, S., Eds.; The MIT Press: Cambridge, MA, USA, 2019.

56. Chen, Y.; Gu, W.; Liu, T.; Yuan, L.; Zeng, M. Increasing the Use of Urban Greenways in Developing Countries: A Case Study on Wutong Greenway in Shenzhen, China. Int. J. Environ. Res. Public Health 2017, 14, 554. [CrossRef] [PubMed] 
57. Larson, L.R.; Keith, S.J.; Fernandez, M.; Hallo, J.C.; Shafer, C.S.; Jennings, V. Ecosystem Services and Urban Greenways: What's the Public's Perspective? Ecosyst. Serv. 2016, 22, 111-116. [CrossRef]

58. Cackowski-Campbell, J.; Augustin, S. Research Design Connections: Studies Show the Benefits of Gardens for the Mentally Ill, Reasons for Walking, and How Greenways Help Preserve Urban Biodiversity. Landsc. Archit. 2006, 96, 72-77.

59. Floress, K.; Baumgart-Getz, A.; Prokopy, L.S.; Janota, J. The Quality of Greenways Planning in Northwest Indiana: A Focus on Sustainability Principles. J. Environ. Plan. Manag. 2009, 52, 61-78. [CrossRef]

60. Hepcan, Ş.; Kaplan, A.; Özkan, B.; Küçükerbaş, E.V.; Yiğit, E.M.; Türel, H.S. Public Space Networks as a Guide to Sustainable Urban Development and Social Life: A Case Study of Muğla, Turkey. Int. J. Sustain. Dev. World Ecol. 2006, 13, 375-389. [CrossRef]

61. Lindsey, G. Sustainability and Urban Greenways: Indicators in Indianapolis. J. Am. Plan. Assoc. 2003, 69, 165-180. [CrossRef]

62. Kang, C.D.; Cervero, R. From Elevated Freeway to Urban Greenway: Land Value Impacts of the CGC Project in Seoul, Korea. Urban Stud. 2009, 46, 2771-2794. [CrossRef]

63. Payton, S.B.; Ottensmann, J.R. The Implicit Price of Urban Public Parks and Greenways: A Spatial-Contextual Approach. J. Environ. Plan. Manag. 2015, 58, 495-512. [CrossRef]

64. Lake, R. FAQ: The Greenway Business Improvement District. In Life on the Greenway; The Rose Kennedy Greenway Conservancy: Boston, MA, USA, 2018.

65. Betsky, A. The High Line Effect: Are Our New Parks Trojan Horses of Gentrification? Metropolis 2016, 36, 76-79.

66. Wolch, J.R.; Byrne, J.; Newell, J.P. Urban Green Space, Public Health, and Environmental Justice: The Challenge of Making Cities 'Just Green Enough'. Landsc. Urban Plan. 2014, 125, 234-244. [CrossRef]

67. Reichhart, T.; Arnberger, A. Exploring the Influence of Speed, Social, Managerial and Physical Factors on Shared Trail Preferences Using a 3D Computer Animated Choice Experiment. Landsc. Urban Plan. 2010, 96, 1-11. [CrossRef]

68. Shafer, C.S.; Lee, B.K.; Turner, S. A Tale of Three Greenway Trails: User Perceptions Related to Quality of Life. Landsc. Urban Plan. 2000, 49, 163-178. [CrossRef]

69. Chon, J.; Shafer, C.S. Aesthetic Responses to Urban Greenway Trail Environments. Landsc. Res. 2009, 34, 83-104. [CrossRef]

70. Akpinar, A. Factors Influencing the Use of Urban Greenways: A Case Study of Aydın, Turkey. Urban For. Urban Green. 2016, 16, 123-131. [CrossRef]

71. Liu, X.; Zhu, Z.; Jin, L.; Wang, L.; Huang, C. Measuring Patterns and Mechanism of Greenway Use-A Case from Guangzhou, China. Urban For. Urban Green. 2018, 34, 55-63. [CrossRef]

72. Burchfield, R.A.; Fitzhugh, E.C.; Bassett, D.R. The Association of Trail Use With Weather-Related Factors on an Urban Greenway. J. Phys. Act. Health 2012, 9, 188-197. [CrossRef]

73. Harris, B.; Larson, L.; Ogletree, S. Different Views From The 606: Examining the Impacts of an Urban Greenway on Crime in Chicago. Environ. Behav. 2018, 50, 56-85. [CrossRef]

74. Coutts, C.; Miles, R. Greenways as Green Magnets: The Relationship between the Race of Greenway Users and Race in Proximal Neighborhoods. J. Leis. Res. 2011, 43, 317-333. [CrossRef]

75. Frank, B.; Delano, D.; Caniglia, B.S. Urban Systems: A Socio-Ecological System Perspective. Sociol. Int. J. 2017, 1, 1-8. [CrossRef]

76. Grove, J.M.; Burch, W.R. A Social Ecology Approach and Applications of Urban Ecosystem and Landscape Analyses: A Case Study of Baltimore, Maryland. Urban Ecosyst. 1997, 1, 259-275. [CrossRef]

77. Chung, C.K.L.; Zhang, F.; Wu, F. Negotiating Green Space with Landed Interests: The Urban Political Ecology of Greenway in the Pearl River Delta, China. Antipode 2018, 50, 891-909. [CrossRef]

78. Safransky, S. Greening the Urban Frontier: Race, Property, and Resettlement in Detroit. Geoforum 2014, 56, 237-248. [CrossRef]

79. Angold, P.G.; Sadler, J.P.; Hill, M.O.; Pullin, A.; Rushton, S.; Austin, K.; Small, E.; Wood, B.; Wadsworth, R.; Sanderson, R.; et al. Biodiversity in Urban Habitat Patches. Sci. Total Environ. 2006, 360, 196-204. [CrossRef]

80. Cook, E.A. Landscape Structure Indices for Assessing Urban Ecological Networks. Landsc. Urban Plan. 2002, 58, 269-280. [CrossRef]

81. Lindsey, G. Use of Urban Greenways: Insights from Indianapolis. Landsc. Urban Plan. 1999, 45, $145-157$. [CrossRef] 
82. Liu, K.; Siu, K.W.M.; Gong, X.Y.; Gao, Y.; Lu, D. Where Do Networks Really Work? The Effects of the Shenzhen Greenway Network on Supporting Physical Activities. Landsc. Urban Plan. 2016, 152, 49-58. [CrossRef]

83. Che, Y.; Yang, K.; Chen, T.; Xu, Q. Assessing a Riverfront Rehabilitation Project Using the Comprehensive Index of Public Accessibility. Ecol. Eng. 2012, 40, 80-87. [CrossRef]

84. Säumel, I.; Kowarik, I. Urban Rivers as Dispersal Corridors for Primarily Wind-Dispersed Invasive Tree Species. Landsc. Urban Plan. 2010, 94, 244-249. [CrossRef]

85. Asakawa, S.; Yoshida, K.; Yabe, K. Perceptions of Urban Stream Corridors within the Greenway System of Sapporo, Japan. Landsc. Urban Plan. 2004, 68, 167-182. [CrossRef]

86. Tuan, Y.-F. Space and Place: The Persepective of Experience; University of Minnesota Press: Minneapolis, MN, USA, 1977.

87. Eisenman, T.S. Greening Cities in an Urbanizing Age: The Human Health Bases in the Nineteenth and Early Twenti-First Centuries. Chang. Time 2016, 6, 216-246. [CrossRef]

88. Feng, Y.; Tan, P.Y. Imperatives for Greening Cities: A Historical Perspective. In Greening Cities: Forms $\mathcal{E}$ Functions; Tan, P.Y., Jim, C.Y., Eds.; Springer: Singapore, 2017; pp. 41-70.

89. Campbell, S. Green Cities, Growing Cities, Just Cities?: Urban Planning and the Contradictions of Sustainable Development. J. Am. Plan. Assoc. 1996, 62, 296-312. [CrossRef]

90. Beatley, T. Green Cities of Europe: Global Lessons on Green Urbanism; Kindle edition; Beatley, T., Ed.; Island Press: Washington, DC, USA, 2012.

91. Earth Day Network. Green Cities. Available online: https://www.earthday.org/campaigns/green-cities/ (accessed on 1 December 2019).

92. Lindfield, M.; Steinberg, F. (Eds.) Green Cities; Urban Development Series; Asian Development Bank: Manila, Philippines, 2012.

93. Schrijnen, P.M. Infrastructure Networks and Red-Green Patterns in City Regions. Landsc. Urban Plan. 2000, 48, 191-204. [CrossRef]

94. Prince George's County, MD. Low-Impact Development Design Strategies; Prince George's County, MD; Department of Environmental Resources: Largo, MD, USA, 1999.

95. City of Philadelphia. Green City, Clean Waters: The City of Philadelphia's Plan for Combined Sewer Overflow Control; Philadelphia Water Department: Philadelphia, PA, USA, 2011; p. 46.

96. City of New York, (Department of Environmental Protection). NYC Green Infrastructure Plan: 2011 Update; The City of New York: New York, NY, USA, 2012.

97. Rottle, N.D.; Maryman, B. Envisioning a City's Green Infrastructure for Community Livability. In Community Livability: Issues and Approaches to Sustaining Well-being of People and Communities; Wagner, F., Caves, R., Eds.; Routledge: Taylor and Francis Group: London, UK, 2012.

98. Gobster, P.H.; Westphal, L.M. The Human Dimensions of Urban Greenways: Planning for Recreation and Related Experiences. Landsc. Urban Plan. 2004, 68, 147-165. [CrossRef]

99. MacGregor-Fors, I. Misconceptions or Misunderstandings? On the Standardization of Basic Terms and Definitions in Urban Ecology. Landsc. Urban Plan. 2011, 100, 347-349. [CrossRef]

100. McIntyre, N.E.; Knowles-Yánez, K.; Hope, D. Urban Ecology as an Interdisciplinary Field: Differences in the Use of "Urban" Between the Social and Natural Sciences. In Urban Ecology; Marzluff, J.M., Shulenberger, E., Endlicher, W., Alberti, M., Bradley, G., Ryan, C., Simon, U., ZumBrunnen, C., Eds.; Springer: Boston, MA, USA, 2008; pp. 49-65.

101. Pickett, S.T.A.; Cadenasso, M.L.; Childers, D.L.; McDonnell, M.J.; Zhou, W. Evolution and Future of Urban Ecological Science: Ecology in, of, and for the City. Ecosyst. Health Sustain. 2016, 2, e01229. [CrossRef]

102. Takacs, D. How Does Positionality Bias Your Epistemology? NEA High. Educ. J. 2003, 27-38.

103. Eisenman, T.S.; Churkina, G.; Jariwala, S.P.; Kumar, P.; Lovasi, G.S.; Pataki, D.E.; Weinberger, K.R.; Whitlow, T.H. Urban Trees, Air Quality, and Asthma: An Interdisciplinary Review. Landsc. Urban Plan. 2019, 187, 47-59. [CrossRef]

104. Menzies, P. Against Causal Reductionism. Mind 1988, 97, 551-574. [CrossRef]

(C) 2020 by the authors. Licensee MDPI, Basel, Switzerland. This article is an open access article distributed under the terms and conditions of the Creative Commons Attribution (CC BY) license (http://creativecommons.org/licenses/by/4.0/). 